\title{
Surface-Renewable AgNPs/CNT/rGO Nanocomposites as Bifunctional Impedimetric Sensors
}

\author{
Azadeh Azadbakht $^{1} \cdot$ Amir Reza Abbasi $^{1} \cdot$ Zohreh Derikvand $^{1} \cdot$ Ziba Karimi $^{1} \cdot$ Mahmoud Roushani $^{2}$
}

Received: 16 July 2016/Accepted: 4 August 2016/Published online: 13 September 2016

(C) The Author(s) 2016. This article is published with open access at Springerlink.com

\begin{abstract}
In this study, glassy carbon electrode modified by silver nanoparticles/carbon nanotube/reduced graphene oxide (AgNPs/CNT/rGO) composite has been utilized as a platform to immobilize cis-dioxomolybdenum (VI)-salicylaldehydehistidine $\left(\mathrm{MoO}_{2} / \mathrm{Sal}-\mathrm{His}\right)$. The modified electrode shows two reversible redox couples for $\mathrm{MoO}_{2} / \mathrm{Sal}$-His. Electrocatalytic oxidation of cysteine ( $\mathrm{CySH})$ and electrocatalytic reduction of iodate on the surface of the modified electrode were investigated with cyclic voltammetry and electrochemical impedance spectroscopy methods. The presence of $\mathrm{MoO}_{2} / \mathrm{Sal}^{-}$ His on AgNPs/CNT/rGO shifted the catalytic current of iodate reduction to a more positive potential and the catalytic current of cysteine oxidation to a more negative potential. The change of interfacial charge transfer resistance $\left(R_{\mathrm{ct}}\right)$ recorded by the modified electrode was monitored for sensitive quantitative detection of $\mathrm{CySH}$ and iodate. Moreover, the sensor has a good stability, and it can be renewed easily and repeatedly through a mechanical or electrochemical process.
\end{abstract}

\section{Graphical Abstract}

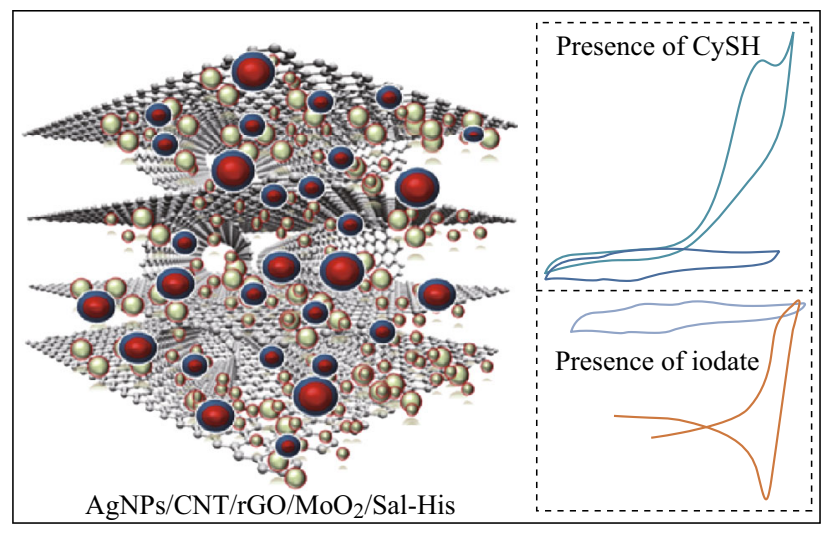

Keywords Silver nanoparticle $\cdot \mathrm{rGO} \cdot \mathrm{MoO}_{2} /$ Sal-His $\cdot$ Cysteine $\cdot$ Iodate

Azadeh Azadbakht

azadbakht.a@gmail.com

1 Department of Chemistry, Faculty of Science, Khorramabad Branch, Islamic Azad University, Khorramabad, Iran

2 Department of Chemistry, Ilam University, Ilam, Iran

\section{Introduction}

As a novel carbon material, graphene, with unique electrical and mechanical properties as well as large surface area, has received particular attention for potential applications in actuators, solar cells, field emission devices, 
field-effect transistors, supercapacitors, and batteries [1-3]. Due to van der Waals interactions, graphene nanosheets tend to agglomerate irreversibly to form graphite [4]. In order to obtain individual graphene sheets, graphene-based nanocomposites such as metal oxide/graphene, polymer/graphene, and nanoparticle/graphene have been successfully designed [5, 6]. Dispersion of metal nanoparticles on graphene sheets is an approach to reduce the aggregation, and therefore graphene-based nanocomposites containing nanoparticles were prepared and also to improve electronic and thermal conductivity. Nowadays, hybrid nanocomposites containing graphene sheets and metallic nanoparticles are expected to have promising potential applications in different areas such as chemical sensors, energy storage, catalysis, and hydrogen storage. Another important feature for attachment of metal nanoparticles to graphene is that the adhesion prohibits the aggregation of the graphene nanosheets in dry state. The metal nanoparticles also function as a spacer, therefore increasing the distance between the graphene nanosheets, which makes both faces of graphene accessible [7-9]. Recently, a simple synthetic route for high-density attachment of AgNPs onto the sides of graphene oxide (GO)-carbon nanotube (CNT) with high nanoparticle coverage has been reported by a simple one-step hydrothermal method without reducing agent [10].

L-Cysteine $(\mathrm{CySH})$ due to its crucial role in biological systems has been the subject of many electrochemical studies from both mechanism and detection aspects [11]. Besides, it is widely used in the food industry as an antioxidant and its deficiency is associated with some disruptions such as slow growth, hair depigmentation, edema, lethargy, liver damage, muscle and fat loss, skin lesions, and weakness. As a consequence, its oxidation and accurate determination at low potential constitute a valuable task and the search for sensitive and selective methods for these purposes continues unabated. Various analytical methods have been applied for the determination of amino acids. Most of them are based on chromatographic separation [12], electrophoretic methods [13], and UV/Vis absorption spectrometry [14]. Among different methodologies used, electrochemical measurements of amino acids have gained considerable interest for electroactive compounds due to their simplicity, low cost, sensitivity, and feasibility for the development of in vivo sensors and chromatographic detectors. For this purpose, a variety of chemically modified electrodes (CMEs) with electrocatalytic properties have been employed in the detection of $\mathrm{CySH}[15,16]$. The reported CMEs have some limitations in linear dynamic range, selectivity, sensitivity, detection limit, and other characteristics. Consequently, it remains a great challenge to fabricate simple, low-cost, stable, sensitive, and selective CMEs that can improve the characteristics of electrocatalytic activity for determination of CySH. Furthermore, iodine is an essential micronutrient and plays a crucial role in the normal function of the thyroid gland. Iodine deficiency disorder (IDD) affects about two billion people and is the leading preventable cause of intellectual disabilities. As a result, detection of iodate $\left(\mathrm{IO}_{3}{ }^{-}\right)$is one of the important topics in food, clinical, and biological science [17].

Usually, an inorganic or organic electrocatalyst shows a single electroreductive or electrooxidative catalytic activity [18]. Designing a bifunctional electrocatalyst, especially those that catalyze both reductions and oxidations, has been a challenge in recent years [19, 20]. In this work, we used a simple and facile one-step method to prepare an AgNPs/CNT/rGO composite for immobilization of $\mathrm{MoO}_{2} / \mathrm{Sal}-\mathrm{His}$ as a bifunctional sensor for the highly sensitive determination of $\mathrm{CySH}$ and iodate. The reduction of graphene oxide and the crystallization of the produced Ag were carried out concurrently in a singlestep reaction by hydrothermal treatment. Silver nanoparticles with a small diameter were well distributed using an optimized amount of silver ammonia complex in the composite. Moreover, $\mathrm{MoO}_{2} / \mathrm{Sal}-\mathrm{His}$ was immobilized on the GC electrode (the electrode denoted as AgNPs/CNT/ $\mathrm{rGO} / \mathrm{MoO}_{2} / \mathrm{Sal}-\mathrm{His}$ ) and then the modified electrode was utilized as a bifunctional sensor for determination of both $\mathrm{CySH}$ and iodate.

\section{Experimental}

\subsection{Chemicals}

Multiwalled carbon nanotubes with $95 \%$ purity (10-20 nm diameter) and $1 \mu \mathrm{m}$ length were obtained from Nanolab (Brighton, MA). Hydrochloric acid (37\%), potassium ferricyanide $\left(\mathrm{K}_{3} \mathrm{Fe}(\mathrm{CN})_{6}\right)$, potassium ferrocyanide $\left(\mathrm{K}_{4} \mathrm{Fe}(\mathrm{CN})_{6} \cdot 4 \mathrm{H}_{2} \mathrm{O}\right)$, potassium iodate, silver nitrate $\left(\mathrm{AgNO}_{3}, 99.7 \%\right)$, graphite powder $(1-2 \mu \mathrm{m})$, potassium chloride $(\mathrm{KCl})$, and $\mathrm{CySH}$ were purchased from Merck (Germany) and Fluka and were used as received without further purification. $\mathrm{MoO}_{2} / \mathrm{Sal}$-His were synthesized, purified, and characterized as previously reported [21]. Solutions were deaerated by bubbling high-purity $(99.99 \%)$ nitrogen gas through them prior to the experiments. All experiments were carried out at the ambient temperature of $25 \pm 1{ }^{\circ} \mathrm{C}$. The electrochemical impedance spectroscopy (EIS) and cyclic voltammetry (CV) measurements were performed in the presence of 0.1 M PBS containing $0.1 \mathrm{M} \mathrm{KCl}$ and $3 \mathrm{mM}[\mathrm{Fe}(\mathrm{CN}) 6]^{3-/ 4-}$ or target molecules. 


\subsection{Apparatus}

Electrochemical experiments were performed using a $\mu$ Autolab III potentiostat/galvanostat (Eco Chemie B.V.) with NOVA 1.8 software. A conventional three-electrode cell was used with an $\mathrm{Ag} / \mathrm{AgCl}$ electrode $(\mathrm{KCl} 3 \mathrm{M})$ as the reference electrode, a Pt wire as the counter electrode, and a modified glassy carbon (GC) electrode as the working electrode. The cell was a one-compartment cell with an internal volume of $10 \mathrm{~mL}$. JENWAY $\mathrm{pH}$ meter (model 3345) was used for $\mathrm{pH}$ measurements. To obtain information about morphology and size of the particles, scanning electron microscopy (SEM) was performed using an $\mathrm{X}-30$ Philips instrument with an acceleration voltage of $25.0 \mathrm{kV}$. Also, Fourier transform infrared (FT-IR) and UV-Vis spectra were recorded by an AVATAR-370 Fourier transform infrared spectroscopy and a Unico 2800 UV/Vis spectrophotometer, respectively.

\subsection{Synthesis and Characterization of $\mathrm{C}_{13} \mathrm{H}_{11} \mathrm{MoN}_{3} \mathrm{O}_{5}$ or $\left[\mathrm{MoO}_{2}\right.$ (Sal-His)]}

The Mo (VI) complex was synthesized based on a previously reported procedure [21]. Firstly, $20 \mathrm{~mL}$ of salicylaldehyde solution $(0.5 \mathrm{M})$ was slowly added into $20 \mathrm{~mL}$ histidine solution $(0.5 \mathrm{M})$. Then $10 \mathrm{~mL}$ aqueous solution of sodium acetate $(2 \mathrm{M})$ was added dropwise, the mixture was stirred for $1 \mathrm{~h}$, and its color changed to deep yellow.

$\mathrm{MoO}_{2}(\mathrm{acac})_{2}$ was also prepared according to a method reported in the literature [22]; then $10 \mathrm{~mL}$ of the prepared $\mathrm{MoO}_{2}(\mathrm{acac})_{2}$ solution $(0.85 \mathrm{M})$ was added to the above solution and the mixture was heated and refluxed for $5 \mathrm{~h}$ under vigorous stirring. The resulting yellow solid was filtered off, washed with several solvents, and dried at room temperature. The solid was dissolved in a minimum amount of DMF and the resulting solution was allowed to stand undisturbed. After a few days, yellow needle crystals were obtained by slow evaporation of the solvent at room temperature.

The IR spectrum of Mo (VI) complex shows a broad band in the $3274-3152 \mathrm{~cm}^{-1}$ region due to the stretching

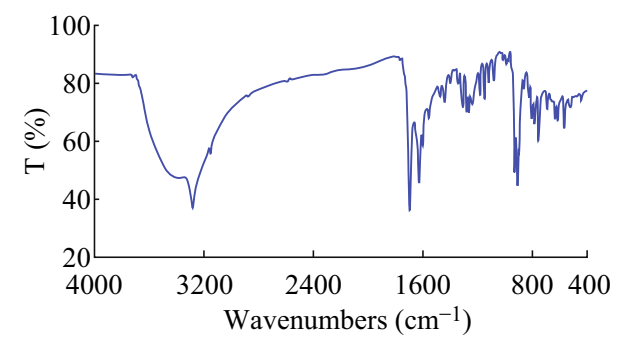

Fig. 1 IR spectrum of $\mathrm{MoO}_{2}$ (Sal-His) complex vibrations of physisorbed water molecules (Fig. 1). No band appeared near $1700 \mathrm{~cm}^{-1}$, confirming the complete deprotonation of carboxyl groups. The strong peaks at 1604 and $1350 \mathrm{~cm}^{-1}$ correspond to the asymmetric and symmetric stretching of carboxyl groups, respectively. The value of $\Delta\left[v_{\mathrm{as}}-v_{\mathrm{s}}\right]$ was $254 \mathrm{~cm}^{-1}$, comparatively larger than $200 \mathrm{~cm}^{-1}$, which is in agreement with the monodentate coordination of the carboxylate group [23]. The sharp peaks at 1556 and $1632 \mathrm{~cm}^{-1}$ are attributed to $v(\mathrm{C}=\mathrm{C})$ and $v(\mathrm{C}=\mathrm{N})$ of the aromatic rings, respectively. The bands in the $930-916 \mathrm{~cm}^{-1}$ region are due to $\mathrm{Mo}=\mathrm{O}$ stretching vibrations [24]. Also, the bands in the range of 524 and $444 \mathrm{~cm}^{-1}$ are attributed to the Mo-O and Mo-N, generated by Mo complexation to the phenol $\mathrm{O}$ and azomethine $\mathrm{N}$ atoms, respectively [25].

The electronic spectrum of the Mo (VI) complex exhibits absorption bands at 268, 280, and $350 \mathrm{~nm}$ which can be assigned to $\pi \rightarrow \pi^{*}$ and $n \rightarrow \pi^{*}$ intraligand transitions of benzene and imine (Fig. 2). The band appearing at $410 \mathrm{~nm}$ may be assigned to ligand-to-metal charge transfer (LMCT). This band was in the range usually observed for $\mathrm{MoO}$ complexes [26].

\subsection{Preparation of AgNPs/CNT/rGO Composite}

In this study, graphene oxides were prepared from graphite via modified Hummers method [27]. For the synthesis of AgNPs/CNT/rGO, silver ammonia $\left[\mathrm{Ag}\left(\mathrm{NH}_{3}\right)_{2} \mathrm{OH}\right]$ solution was obtained by adding ammonia $(1 \mathrm{wt} \%)$ to silver nitrate solution $(50 \mathrm{mM})$ until the precipitates were visually invisible to the naked eye. The concentration of the synthesized $\mathrm{Ag}\left(\mathrm{NH}_{3}\right)_{2} \mathrm{OH}$ was approximately $40 \mathrm{mM}$. The water dispersions of CNT and GO $\left(1.0 \mathrm{mg} \mathrm{mL}^{-1}\right)$ were prepared in separate containers. The solutions of CNT and GO were mixed in the ratio of $3: 1(\mathrm{v} / \mathrm{v})$. AgNPs/CNT/rGO was prepared by mixing the freshly prepared $\mathrm{Ag}\left(\mathrm{NH}_{3}\right)_{2} \mathrm{OH}$ solution with an aqueous solution of $\mathrm{CNT} / \mathrm{GO}$ $\left(1.0 \mathrm{mg} \mathrm{mL}^{-1}\right)(3: 1, \mathrm{v} / \mathrm{v})$ in a volume ratio of $1: 12$ [10] under stirring for $30 \mathrm{~min}$. The mixture was placed in an autoclave and heated at $170{ }^{\circ} \mathrm{C}$ for $4 \mathrm{~h}$. After being cooled to room temperature, the product was isolated by

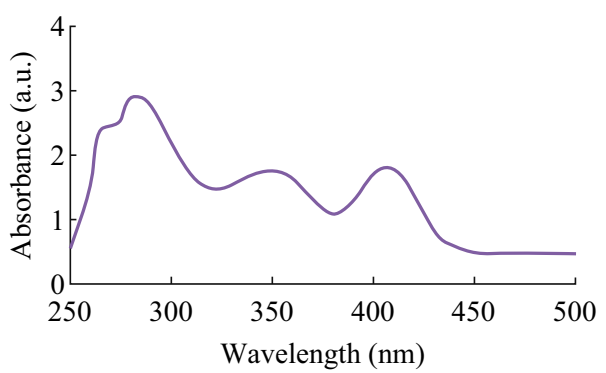

Fig. 2 UV-Vis spectrum of $\mathrm{MoO}_{2}$ (Sal-His) complex 
centrifugation and the obtained precipitate was filtered and dried overnight at $50{ }^{\circ} \mathrm{C}$.

\subsection{Electrode Modification}

To prepare a modified electrode, GC electrode was polished with an emery paper followed by alumina (1.0 and $0.05 \mu \mathrm{m})$ and then thoroughly washed with double-distilled water. Afterward, this electrode was placed in an ethanol container and then a bath ultrasonic cleaner was used to remove the adsorbed particles. To obtain AgNPs/CNT/rGO nanocomposite-modified electrodes, $1 \mathrm{mg}$ of AgNPs/CNT/ rGO composite was dispersed in double-distilled water ( $1 \mathrm{~mL}$ ) by 30 -min mild ultrasonication to obtain a homogeneous suspension. After that, a certain amount $(10 \mu \mathrm{L})$ of the prepared suspension was dropped onto the well-polished GC electrode surface and dried at room temperature for $24 \mathrm{~h}$.

Afterward, the electrode was thoroughly rinsed with water and kept at room temperature for further use. For $\mathrm{MoO}_{2} /$ Sal-His immobilization, $\mathrm{MoO}_{2} / \mathrm{Sal}-\mathrm{His}$ was immobilized on the surface of the modified electrode by immersing AgNPs/CNT/rGO in $0.1 \mathrm{M}$ phosphate buffer solution (PBS, $\mathrm{pH}=2$ ) containing $7 \times 10^{-3} \mathrm{M} \mathrm{MoO}_{2} /$ Sal-His. Then the electrode potential was cycled between -0.3 and $0.8 \mathrm{~V}$ at a scan rate of $50 \mathrm{mV} \mathrm{s}^{-1}$ for 40 cycles. The other used electrodes such as CNT/GC and rGO/GC electrodes were fabricated by casting $10 \mu \mathrm{L}$ of CNT and rGO on the surface of bare GC electrode, respectively. In order to fabricate the AgNPs/GC electrode, AgNPs were electrochemically deposited by potentiostatic deposition, according to a one-step procedure reported in the literature [28], applying a constant potential of $-0.40 \mathrm{~V}$ to a working electrode soaked in a solution containing $5 \times 10^{-3} \mathrm{M}$ $\mathrm{AgNO}_{3}$ and $0.1 \mathrm{M} \mathrm{KNO}_{3}$ for $10 \mathrm{~s}$.

\section{Results and Discussion}

\subsection{Characterization of the Modified Electrode by SEM}

Figure 3 shows the SEM images of CNT/GC (Fig. 3a), CNT/rGO/GC (Fig. 3b) AgNPs/CNT/rGO/GC (Fig. 3c), and $\mathrm{AgNPs} / \mathrm{CNT} / \mathrm{rGO} / \mathrm{MoO}_{2} / \mathrm{Sal}-\mathrm{His} / \mathrm{GC}$ electrodes (Fig. 3d). As shown in Fig. 3b, it can be observed that the carbon nanotubes are impregnated in the matrix of rGO. As shown in Fig. 3c, the AgNPs are decorated on the crumpled thin layer of rGO and CNT. It can be seen in Fig. 3d that after $\mathrm{MoO}_{2} /$ Sal-His immobilization, the surface of the AgNPs/CNT/rGO nanocomposite becomes rougher and the morphology of the electrode surface changed obviously, which implies that the $\mathrm{MoO}_{2} / \mathrm{Sal}-\mathrm{His}$ is successfully deposited on the surface of the AgNPs/CNT/rGO electrode. This result indicates that the film has a globular structure with relatively homogeneous distribution in the range of $70-95 \mathrm{~nm}$. To confirm the formation of AgNPs on the surface of electrode, energy-dispersive X-ray (EDX) mapping analysis was used, and the distribution of AgNPs is shown in Fig. 3e.

\subsection{Electrochemical Behavior of AgNPs/CNT/rGO}

$\mathrm{CV}$ results of bare GC, $\mathrm{GGO} / \mathrm{GC}, \mathrm{CNT} / \mathrm{GC}, \mathrm{AgNPs} / \mathrm{GC}$, and $\mathrm{AgNPs} / \mathrm{CNT} / \mathrm{rGO} / \mathrm{GC}$ in $0.1 \mathrm{M}$ PBS (pH 6.0) containing $0.1 \mathrm{M} \mathrm{KCl}$ and $3 \mathrm{mM}\left[\mathrm{Fe}(\mathrm{CN})_{6}\right]^{3-/ 4-}$ are shown in Fig. 4a-e. The CV curves of ferricyanide were chosen as a marker to investigate the changes of the electrode behavior before and after each assembly step. As it is obvious from Fig. 4, the $\mathrm{CV}$ curves of $\left[\mathrm{Fe}(\mathrm{CN})_{6}\right]^{3-/ 4-}$ redox couple system at the bare $\mathrm{GC}, \mathrm{rGO} / \mathrm{GC}$, and $\mathrm{CNT} / \mathrm{GC}$ show a reversible one-electron redox wave. The peak currents of modified electrodes are considerably increased in the order of $\mathrm{rGO} / \mathrm{GC}<$ bare $\mathrm{GC}<\mathrm{CNT} / \mathrm{GC}$. In fact, $\mathrm{CNT}$ provides a large effective surface area of increased conductivity, compared with the cases of rGO and bare GC electrodes.

AgNPs/GC electrode (curve " $d$ ") shows a very sharp oxidation peak at $+0.15 \mathrm{~V}$, followed by a single reduction feature at $-0.1 \mathrm{~V}$ (redox peaks I-I'), confirming the successful immobilization of AgNPs on the GC electrode surface. Redox peaks II-II' correspond to the $\left[\mathrm{Fe}(\mathrm{CN})_{6}\right]^{3-/ 4-}$ redox couple. In order to enhance the surface area of the electrode, improvement of the electrode was carried out by casting AgNPs/CNT/rGO nanocomposite at the surface of GC electrode. As shown in curve " $e$ ", the peak currents increase 2.5 times higher than that obtained with the CNT/GC electrode. Since the anodic peaks of both $\mathrm{Ag} / \mathrm{Ag}^{+}$and $\left[\mathrm{Fe}(\mathrm{CN})_{6}\right]^{3-/ 4-}$ appear in the close potential region, the $\mathrm{CV}$ curves of $\mathrm{AgNPs} / \mathrm{CNT} / \mathrm{rGO} / \mathrm{GC}$ containing $\left[\mathrm{Fe}(\mathrm{CN})_{6}\right]^{3-/ 4-}$ is the sum of the electrochemical signals of $\mathrm{Ag} / \mathrm{Ag}^{+}$and $\left[\mathrm{Fe}(\mathrm{CN})_{6}\right]^{3-/ 4-}$. These results clearly indicate that AgNPs/ $\mathrm{CNT} / \mathrm{rGO}$ has been successfully immobilized on GC electrode.

Electrochemical impedance spectroscopy (EIS) is an effective technique for probing the features of surfacemodified electrodes. Figure 5a-e, respectively, shows the typical Nyquist plots of GC, rGO/GC, AgNPs/GC, CNT/ GC, and AgNPs/CNT/rGO/GC electrodes recorded in $0.1 \mathrm{M}$ PBS solution containing $0.1 \mathrm{M} \mathrm{KCl}$ and $3 \mathrm{mM}$ $\mathrm{Fe}(\mathrm{CN})_{6}{ }^{3-14-}$ as an electrochemical redox marker. The straight line at low frequency is related to the diffusion process known as Warburg element, while the high-frequency semicircle is related to the electron transfer resistance $\left(R_{\mathrm{ct}}\right)$, which controls the electron transfer kinetics of the redox probe at the electrode interface. The bare GC electrode shows a small electron transfer resistance 

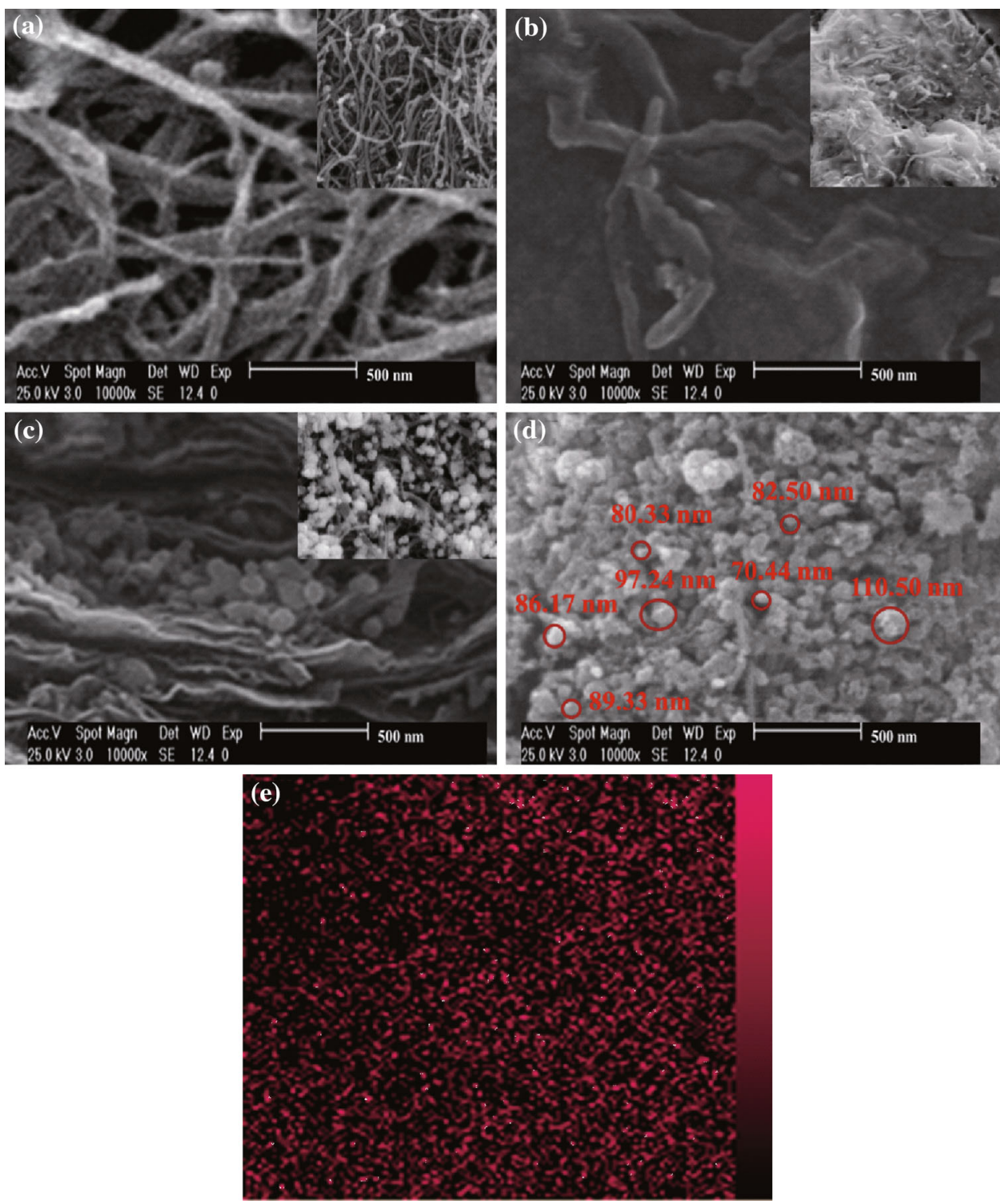

Fig. 3 a Typical SEM images of CNT/GC, b CNT/rGO/GC, c AgNPs/CNT/rGO/GC, and d AgNPs/CNT/rGO/MoO $/ 2 / \mathrm{Sal}-\mathrm{His} / \mathrm{GC}$ electrodes; e EDX mapping analysis of AgNPs

indicating a fast electron transfer process (curve " $a$ "). The diffusion-limited behavior at low frequencies is described by Warburg impedance. Modification of GC electrode with rGO effectively retarded the interfacial electron transfer kinetics of $\left[\mathrm{Fe}(\mathrm{CN})_{6}\right]^{3-/ 4-}$ anions, which is reflected by the increase of $R_{\text {ct }}$ value to about $1.2 \mathrm{k} \Omega$ (curve " $b$ "). It indicates the hindrance to electron transfer, confirming the successful immobilization of rGO on GC electrode surface. Electrodeposition of AgNPs on the surface of GC electrode (curve " $c$ ") results in the decrease of $\mathrm{R}_{\mathrm{ct}}$ value compared with bare GC electrode. When CNT was casted on the surface of GC electrode, the value of $R_{\mathrm{ct}}$ was further decreased to about $270 \Omega$ (curve " $d$ ") compared with bare $\mathrm{GC}$ and AgNPs/GC electrodes, revealing the promoted conductivity of the CNT. Immobilization of AgNPs/CNT/ rGO on the surface of the modified electrode causes a large decrease of $R_{\mathrm{ct}}$ value (curve " $e$ "), indicating that the AgNPs/CNT/rGO film could provide good electron conduction pathways between the electrode and the electrolyte.

\subsection{Electrochemical Behavior of AgNPs/CNT/rGO/ $\mathrm{MoO}_{2} / \mathrm{Sal}-\mathrm{His}$ Electrode}

$\mathrm{CV}$ curves of $\mathrm{AgNPs} / \mathrm{CNT} / \mathrm{rGO} / \mathrm{MoO}_{2} / \mathrm{Sal}$-His modified electrode were recorded in a $\mathrm{pH} 2.0$ buffer solution. Immobilization of the $\mathrm{MoO}_{2} / \mathrm{Sal}$-His on the AgNPs/CNT/ rGO electrode shows two well-defined redox couples with 


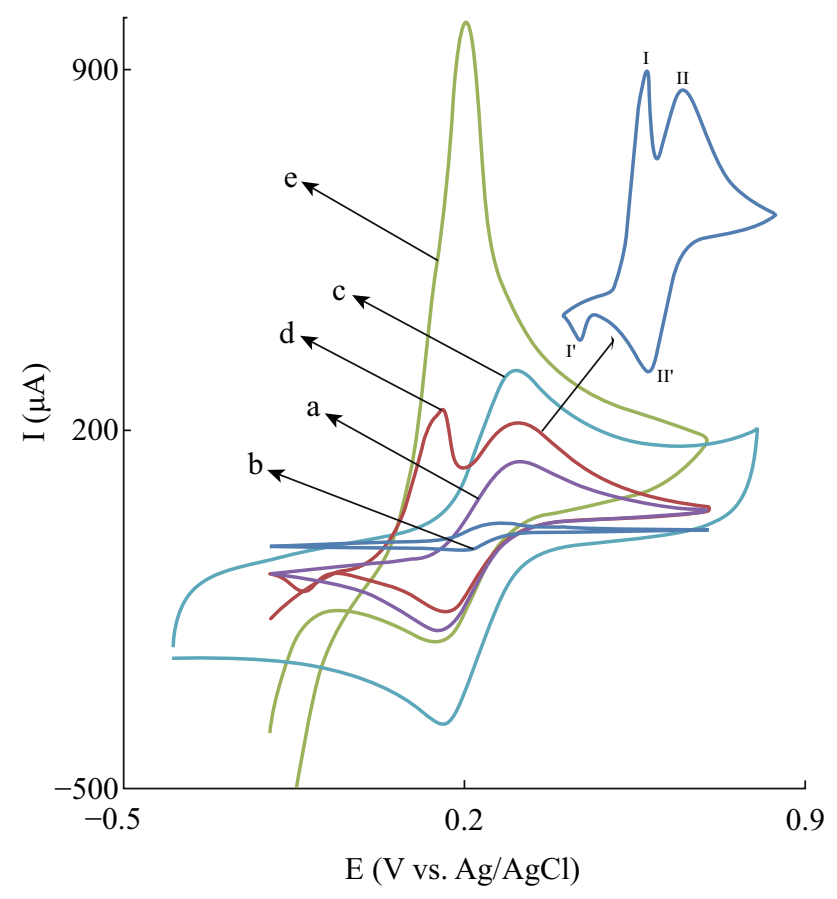

Fig. $4 \mathrm{CV}$ curves of $a$ bare GC, $b$ rGO/GC, $c$ CNT/GC, $d$ AgNPs/ $\mathrm{GC}$, and $e \mathrm{AgNPs} / \mathrm{CNT} / \mathrm{rGO} / \mathrm{GC}$ in $0.1 \mathrm{M}$ PBS (pH 6.0) containing $0.1 \mathrm{M} \mathrm{KCl}$ and $3 \mathrm{mM}\left[\mathrm{Fe}(\mathrm{CN})_{6}\right]^{3-/ 4-}$ at a scan rate of $50 \mathrm{mV} \mathrm{s}^{-1}$

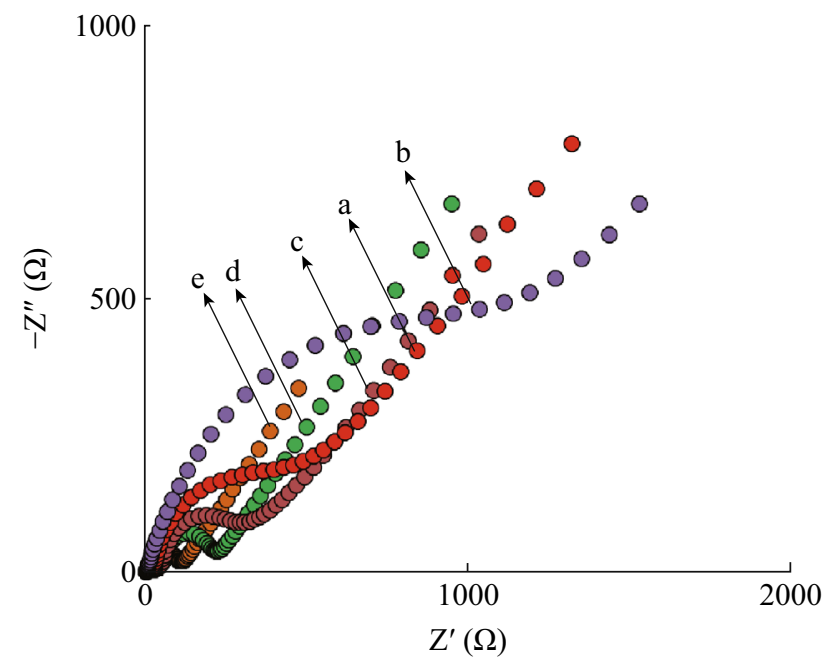

Fig. 5 Nyquist plots for various electrodes of $a \mathrm{GC}, b \mathrm{rGO} / \mathrm{GC}$, $c$ AgNPs/GC, $d$ CNT/GC, and $e$ AgNPs/CNT/rGO/GC in $0.1 \mathrm{M}$ PBS containing $0.1 \mathrm{M} \mathrm{KCl}$ and $3 \mathrm{mM} \mathrm{Fe}(\mathrm{CN})_{6}{ }^{3-/ 4-}$ in the frequency range of $10 \mathrm{kHz}-0.1 \mathrm{~Hz}$

the formal potentials $\left(E^{0 \prime}\right)$ of 0.22 and $0.41 \mathrm{~V}$, respectively. The electrochemical reactions of two redox couples in acidic solutions might be given as follows [29]:

$\mathrm{Mo}^{\mathrm{VI}} \mathrm{O}_{2} /$ Sal-His $+2 \mathrm{H}^{+}+2 \mathrm{e}^{-} \rightarrow \mathrm{Mo}^{\mathrm{V}} \mathrm{O}_{2}\left(\mathrm{H}_{2} \mathrm{O}\right) /$ Sal-His

$$
\begin{aligned}
& \mathrm{Mo}^{\mathrm{V}} \mathrm{O}_{2}\left(\mathrm{H}_{2} \mathrm{O}\right) / \mathrm{Sal}-\mathrm{His}+2 \mathrm{H}^{+}+2 e^{-} \\
& \quad \rightarrow \mathrm{Mo}^{\mathrm{III}}\left(\mathrm{H}_{2} \mathrm{O}\right)_{2} / \text { Sal-His. }
\end{aligned}
$$

The $\mathrm{CV}$ curves of the AgNPs/CNT/rGO/ $\mathrm{MoO}_{2} / \mathrm{Sal}-\mathrm{His}$ modified electrode in PBS ( $\mathrm{pH} 2.0$ ) at different scan rates are shown in Fig. 6a. The peak currents of the voltammograms are linearly proportional to the scan rate $(v)$ of up to $200 \mathrm{mV} \mathrm{s}^{-1}$ for the peak currents of I-I and II-II' (Fig. 6b), confirming the surface-type reactions. However, the peak potential differences $\left(\Delta E_{\mathrm{p}}\right)$ are larger than the theoretical value $(0 \mathrm{mV})$ expected for a reversible surface redox process [30] and increase with the increasing scan rate, which might be due to the non-ideal behavior [31, 32].

\subsection{Electrocatalytic Activity of Modified Electrodes}

Oxidation of $\mathrm{CySH}$ on the surface of AgNPs/CNT/rGO electrode and $\mathrm{AgNPs} / \mathrm{CNT} / \mathrm{rGO} / \mathrm{MoO}_{2} / \mathrm{Sal}$-His electrodes was investigated in $0.1 \mathrm{M}$ PBS (pH 6.0). Figure 7a shows the recorded $\mathrm{CV}$ curves in the absence and the presence of $5 \mathrm{mM}$ CySH in AgNPs/CNT/rGO (curves 1 and 2) and AgNPs/CNT/rGO/MoO $/ 2 /$ Sal-His (curve 3 and 4 ) electrodes at a scan rate of $50 \mathrm{mV} \mathrm{s}^{-1}$. No electrochemical response was observed on AgNPs/CNT/rGO electrode in the absence of CySH (curve 1), but in the presence of CySH a small redox response can be observed at the potential of $0.6 \mathrm{~V}$ (curve 2). However, under the same conditions in $\mathrm{AgNPs} / \mathrm{CNT} / \mathrm{rGO} / \mathrm{MoO}_{2} / \mathrm{Sal}-\mathrm{His}$ electrode, the oxidation current of $\mathrm{CySH}$ starts at $0 \mathrm{~V}$ and an obvious catalytic oxidation occurs at the potential of $0.05 \mathrm{~V}$ (curve 4). It can be seen that the peak potential for oxidation of $\mathrm{CySH}$ is significantly shifted to a more negative potential $(0.05 \mathrm{~V}$

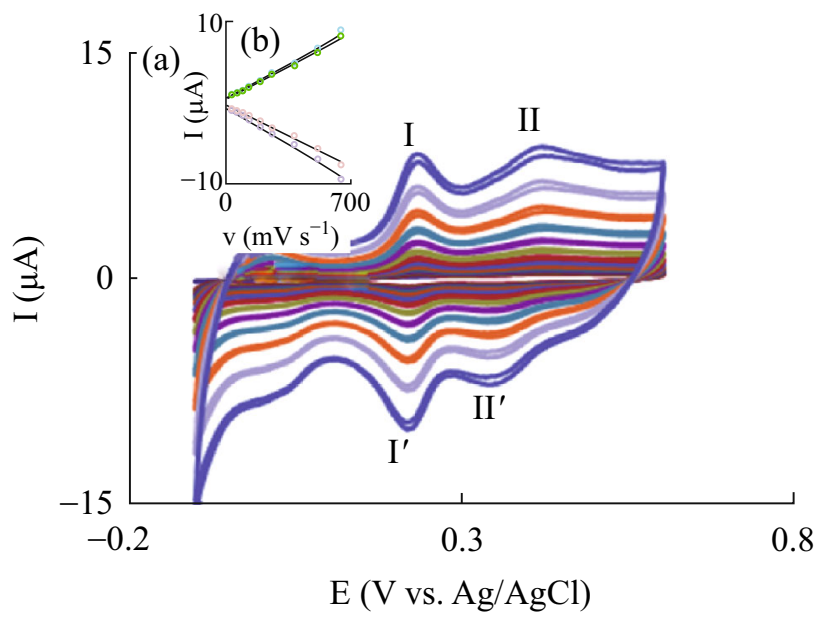

Fig. $6 a \mathrm{CV}$ curves of the AgNPs/CNT/rGO/ $/ \mathrm{MoO}_{2} / \mathrm{Sal}-\mathrm{His}$ electrode in PBS (pH 2.0) at different scan rates: 10, 25, 50, 75, 100, 150, 200, 300,400 , and $500 \mathrm{mV} \mathrm{s}^{-1} . b$ Variation of the anodic and cathodic peak currents of the electrode versus potential scan rate 


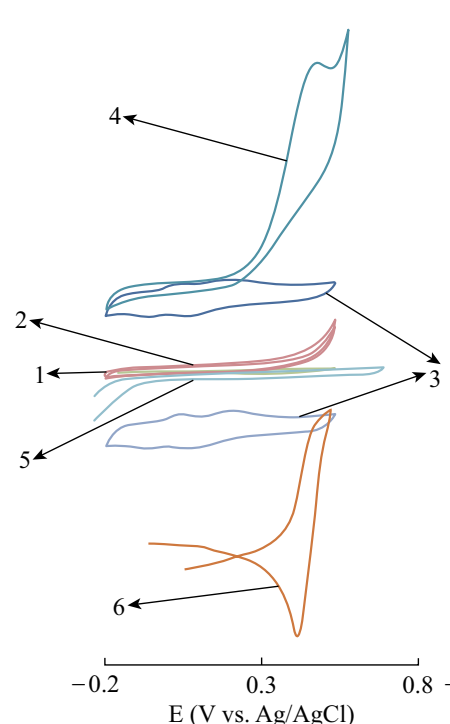

(a)

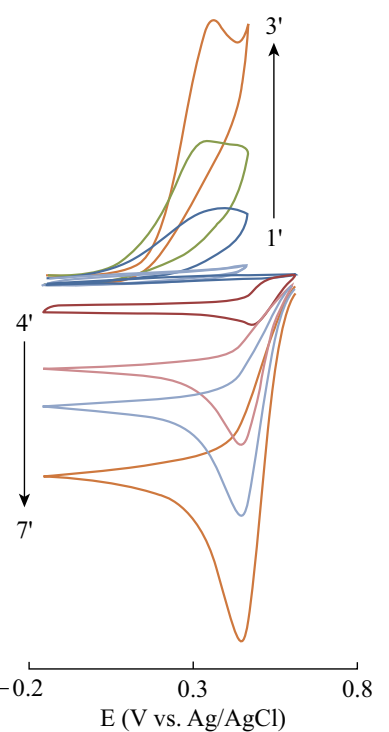

(b)
Fig. 7 a $\mathrm{CV}$ curves of $\mathrm{AgNPs} / \mathrm{CNT} / \mathrm{rGO} / \mathrm{GC}$ (1 and 2) and AgNPs/ $\mathrm{CNT} / \mathrm{rGO} / \mathrm{MoO}_{2} / \mathrm{Sal}-\mathrm{His} / \mathrm{GC}$ (3 and 4 ) in the absence (1 and 3 ) and the presence (2 and 4) of $5 \mathrm{mM}$ of CySH in $0.1 \mathrm{M} \mathrm{PBS}(\mathrm{pH} \mathrm{6.0)}$ ) at a scan rate of $50 \mathrm{mV} \mathrm{s}^{-1}$. CV curves of AgNPs/CNT/rGO/GC (1 and 5) and $\mathrm{AgNPs} / \mathrm{CNT} / \mathrm{rGO} / \mathrm{MoO}_{2} / \mathrm{Sal}-\mathrm{His} / \mathrm{GC}$ (3 and 6 ) in the absence $(1$ and 3) and the presence (5 and 6) of $2 \mathrm{mM}$ iodate in $0.1 \mathrm{M} \mathrm{PBS}(\mathrm{pH}$ 2.0) at a scan rate of $50 \mathrm{mV} \mathrm{s}^{-1}$. b CV curves of the AgNPs/CNT/ $\mathrm{rGO} / \mathrm{MoO}_{2} / \mathrm{Sal}-\mathrm{His} / \mathrm{GC}$ at a scan rate of $50 \mathrm{mV} \mathrm{s}^{-1}$ at different concentrations of $\mathrm{CySH}\left(1^{\prime}-3^{\prime}\right)$ of 5,15 , and $30 \mathrm{mM}$ and iodate $\left(4^{\prime}-\right.$ $\left.6^{\prime}\right)$ of $0.5,2$, and $5 \mathrm{mM}$

vs. $\mathrm{Ag} / \mathrm{AgCl}$ ) compared with $\mathrm{AgNPs} / \mathrm{CNT} / \mathrm{rGO}$ modified electrode $(0.6 \mathrm{~V}$ vs. $\mathrm{Ag} / \mathrm{AgCl})$. Furthermore, the anodic peak current is greatly enhanced in the presence of $\mathrm{CySH}$ and the reduction peak current totally disappeared, suggesting a typical electrocatalytic oxidation process. The substantially decreasing overvoltage and increasing oxidation peak current of CySH confirm that $\mathrm{MoO}_{2} / \mathrm{Sal}-\mathrm{His}$ immobilized on $\mathrm{AgNPs} / \mathrm{CNT} / \mathrm{rGO}$ electrode can act as an efficient mediator to shuttle electrons between $\mathrm{CySH}$ and the working electrode. With increasing the concentration of $\mathrm{CySH}$, the anodic current density is enhanced and the corresponding reduction current density is decreased (Fig. $7 b$, curve $1^{\prime}-3^{\prime}$ ).

Electrocatalytic reduction of iodate on the surface of the proposed modified electrode was also evaluated by $\mathrm{CV}$. Reduction peak current of iodate at the surface of AgNPs/ $\mathrm{CNT} / \mathrm{rGO}$ and $\mathrm{AgNPs} / \mathrm{CNT} / \mathrm{rGO} / \mathrm{MoO}_{2} / \mathrm{Sal}$-His electrodes was recorded in PBS ( $\mathrm{pH} 2.0$ ) containing $2 \mathrm{mM}$ of iodate at a scan rate of $50 \mathrm{mV} \mathrm{s}^{-1}$. The reduction current of iodate appeared at the potential of $-0.3 \mathrm{~V}$ at the surface of $\mathrm{AgNPs} / \mathrm{CNT} / \mathrm{rGO}$ in the PBS (pH 2.0) (curve 5). However, the presence of $\mathrm{MoO}_{2} / \mathrm{Sal}-\mathrm{His}$ film on AgNPs/CNT/rGO shifts the catalytic current of iodate reduction to a more positive potential (curve 6) compared with AgNPs/CNT/ rGO modified electrode. These results indicate that $\mathrm{MoO}_{2} /$
Sal-His exhibits an excellent catalytic activity toward iodate reduction. With increasing the concentration of iodate, the cathodic current density is enhanced and the corresponding oxidation current density is decreased (Fig. 7b, curve $4^{\prime}-7^{\prime}$ ).

Furthermore, CV curves of different concentrations of $\mathrm{CySH}$ at the modified electrode in $0.1 \mathrm{M}$ PBS (pH 6.0) were recorded (Fig. 8a). The data reveal that the calibration curve is linear, with the CySH concentration in the range of $5-150 \mathrm{mM}$ and a correlation coefficient of 0.996 (Fig. 8b).

As illustrated in Fig. 8a (magnification in Fig. 8a), when the concentration of $\mathrm{CySH}$ is enhanced, the anodic peak current of the modified electrode increases, whereas its cathodic peak current diminishes, indicating a typical electrocatalytic oxidation process $\left(\mathrm{EC}^{\prime}\right)$. Hence, a possible mechanism of CySH electrooxidation on AgNPs/CNT/ $\mathrm{rGO} / \mathrm{MoO}_{2} / \mathrm{Sal}$-His electrode might be given as follows:

$\mathrm{CySH} \rightarrow \mathrm{Cys}^{-}+\mathrm{H}^{+}$

$\begin{aligned} \mathrm{Mo}^{\mathrm{III}}\left(\mathrm{H}_{2} \mathrm{O}\right)_{2} / \text { Sal-His } \rightarrow & \mathrm{Mo}^{\mathrm{V}} \mathrm{O}_{2}\left(\mathrm{H}_{2} \mathrm{O}\right) / \mathrm{Sal}-\mathrm{His}+2 \mathrm{H}^{+} \\ & +2 \mathrm{e}^{-}\end{aligned}$

$\mathrm{Mo}^{\mathrm{V}} \mathrm{O}_{2}\left(\mathrm{H}_{2} \mathrm{O}\right) /$ Sal-His $+\mathrm{Cys}^{-}+2 \mathrm{H}^{+}+\mathrm{e}^{-}$

$\rightarrow \mathrm{Mo}^{\mathrm{III}}\left(\mathrm{H}_{2} \mathrm{O}\right)_{2} /$ Sal-His + Cys

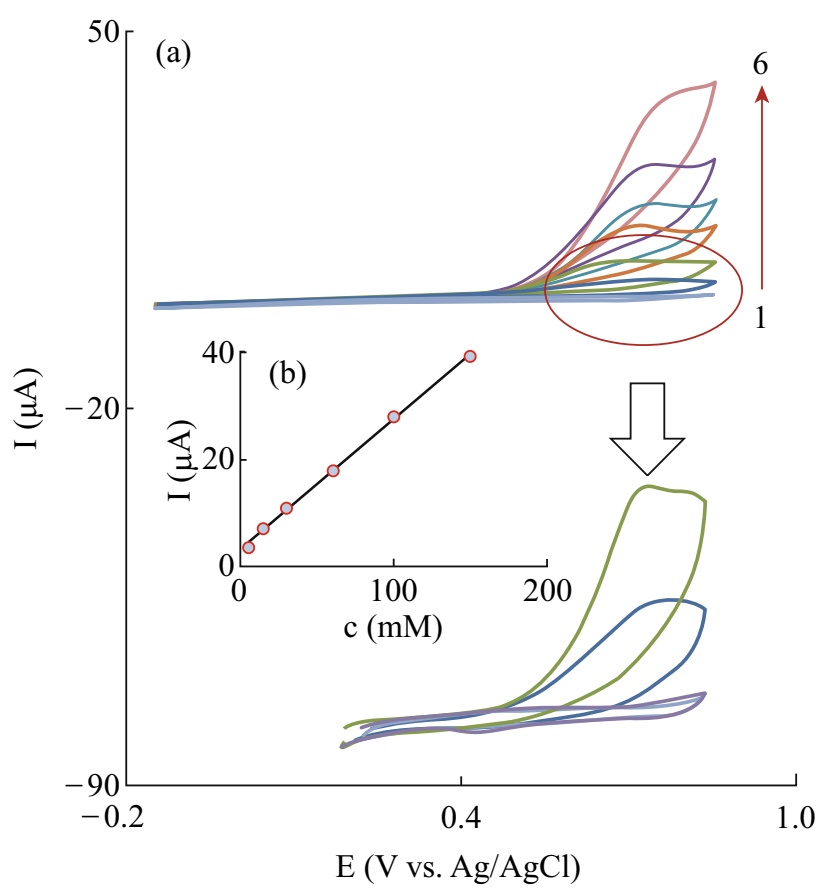

Fig. 8 a $\mathrm{CV}$ curves of the AgNPs/CNT/rGO/MoO $/ 2 / \mathrm{Sal}-\mathrm{His} / \mathrm{GC}$ in the presence of $\mathrm{CySH}$ with different concentrations (1-6) of 5, 15, 30, $60,100,150 \mathrm{mM}$ in $0.1 \mathrm{M}$ PBS (pH 6.0) at a scan rate of $50 \mathrm{mV} \mathrm{s}^{-1}$. $b$ Plot of catalytic peak versus $\mathrm{CySH}$ concentration 


$$
2 \text { Cys } \rightarrow \text { CySSCy }
$$

This is similar to the mechanism reported previously for CySH oxidation on solid electrodes [33, 34]. A possible mechanism for CySH oxidation at the surface of AgNPs/ $\mathrm{CNT} / \mathrm{rGO} / \mathrm{MoO}_{2} / \mathrm{Sal}-\mathrm{His}$ might be given as follows:

$$
\begin{aligned}
& \mathrm{CySH} \leftrightarrow \mathrm{CyS}^{-} \\
& \mathrm{Cys}^{-} \rightarrow \mathrm{CyS}+\mathrm{e}^{-} \\
& 2 \mathrm{CyS}^{-} \rightarrow \mathrm{CySSCy} .
\end{aligned}
$$

The EIS results obtained in the presence of increasing concentration of $\mathrm{CySH}$ at the surface of the modified $\mathrm{AgNPs} / \mathrm{CNT} / \mathrm{rGO} / \mathrm{MoO}_{2} / \mathrm{Sal}$-His electrode are shown in Fig. 9a. As shown in Fig. 9b, there is a linear relationship between $R_{\text {ct }}$ and the concentration of CySH over a concentration range of 1.0 to $40.0 \mathrm{nM}\left(R^{2}=0.992\right)$. The limit of detection (LOD) of this method was calculated at a concentration level of $300 \mathrm{pM}$.

Figure 10a shows the modified electrode response in the presence of different concentrations of iodate in 0.1 M PBS $(\mathrm{pH}$ 2.0). The cathodic peak current increases with increasing iodate concentrations in the range of $500 \mu \mathrm{M}$ to $170 \mathrm{mM}$ with a correlation coefficient of 0.996 . As shown in Fig. 10b, the cathodic peak current is significantly enhanced in the presence of iodate accompanied by the disappearance of the oxidation peak, suggesting an excellent electrocatalytic reduction process. Increasing the concentration of iodate will increase the cathodic and reduce the anodic peak currents, indicating a typical electrocatalytic reduction process $\left(\mathrm{EC}^{\prime}\right)$.

In order to optimize the electrocatalytic response condition, the effect of $\mathrm{pH}$ on the electrocatalytic activity of the modified electrodes for the reduction of iodate was examined by monitoring the $\mathrm{CV}$ curves of AgNPs/CNT/

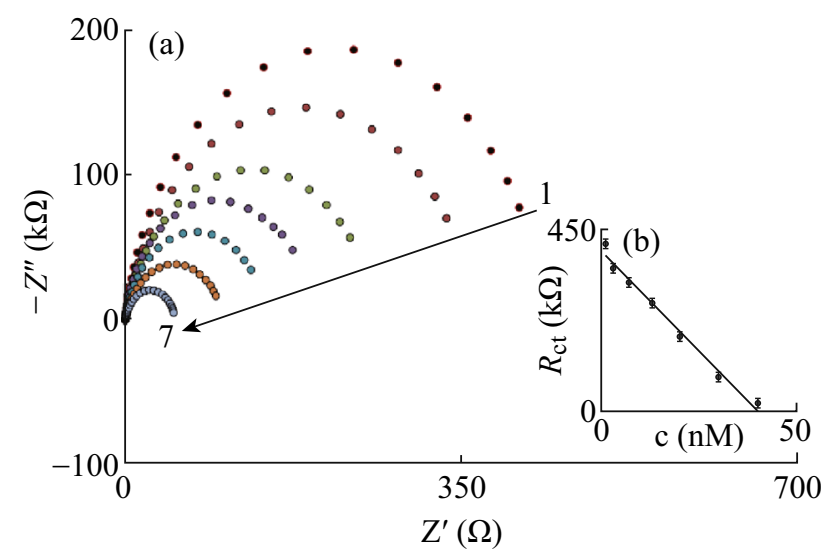

Fig. $9 a$ EIS response of AgNPs/CNT/rGO/MoO $/ \mathrm{Mal}_{2} / \mathrm{His} / \mathrm{GC}$ in the presence of $\mathrm{CySH}$ with different concentrations (1-7) of 1, 3, 7, 13, 20, 30, and $40 \mathrm{nM}$ in $0.1 \mathrm{M}$ PBS (pH 6.0) at the frequency range of $10 \mathrm{kHz}-0.1 \mathrm{~Hz} . b$ Corresponding calibration plot of $R_{\mathrm{ct}}$ versus CySH concentration

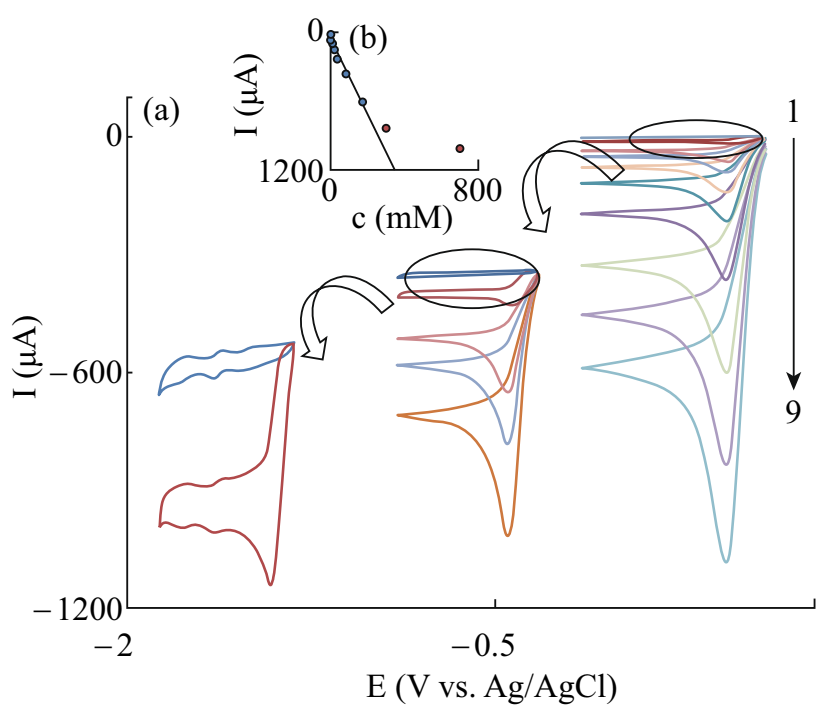

Fig. 10 a $\mathrm{CV}$ curves of $\mathrm{AgNPs} / \mathrm{CNT} / \mathrm{rGO} / \mathrm{MoO}_{2} / \mathrm{Sal}-\mathrm{His} / \mathrm{GC}$ in the presence of iodate with different concentrations (1-9) of $0.5,2,5,15$, $35,80,170,300$, and $700 \mathrm{mM}$ in $0.1 \mathrm{M}$ PBS (pH 2.0) at a scan rate of $50 \mathrm{mV} \mathrm{s}^{-1}$. $b$ Plot of catalytic peak versus iodate concentration

$\mathrm{rGO} / \mathrm{MoO}_{2} / \mathrm{Sal}$-His electrode in the presence of $2 \mathrm{mM}$ of iodate in $0.1 \mathrm{M}$ buffer solution with different $\mathrm{pH}$ values (not shown). In the $\mathrm{pH}$ range of 1-3, the modified electrode exhibits electrocatalytic activity, but the current density for iodate reduction decreases as the $\mathrm{pH}$ of solution increases from 3. The higher peak currents were observed at $\mathrm{pH} 2$ because the reduction reaction of iodate depends strongly on the concentration of proton, as can be seen in Eq. (10):

$\mathrm{IO}_{3}^{-}+6 \mathrm{H}^{+}+6 \mathrm{e}^{-} \rightarrow \mathrm{I}^{-}+3 \mathrm{H}_{2} \mathrm{O}$.

Impedimetric detection of iodate at the modified electrode under the optimized conditions was recorded and the relationship between $R_{\mathrm{ct}}$ values and the concentrations of iodate was studied.

For this purpose, the modified electrode was introduced into the solutions containing various concentrations of iodate, and the results are also shown in Fig. 11a. It is obvious that the semicircle begins to change and its diameter decreased gradually with increasing iodate concentration. The calibration plot between 5 and $150 \mathrm{nM}$ consists of two linear (5-50 and 70-150 nM) segments with different slopes, corresponding to two different ranges of iodate concentration (Fig. 11b).

In the concentration range of $5-50 \mathrm{nM}$, the correlation coefficient is 0.994 and the detection limit was calculated as $1.2 \mathrm{nM}$ (based on signal/noise $[S / N]=3$ ). Therefore, the proposed modified electrode can successfully detect iodate with high sensitivity and a low detection limit. The detection limit, linear calibration range, and applied potential for $\mathrm{CySH}$ and iodate detection are listed in Table 1. These analytical parameters for the proposed 


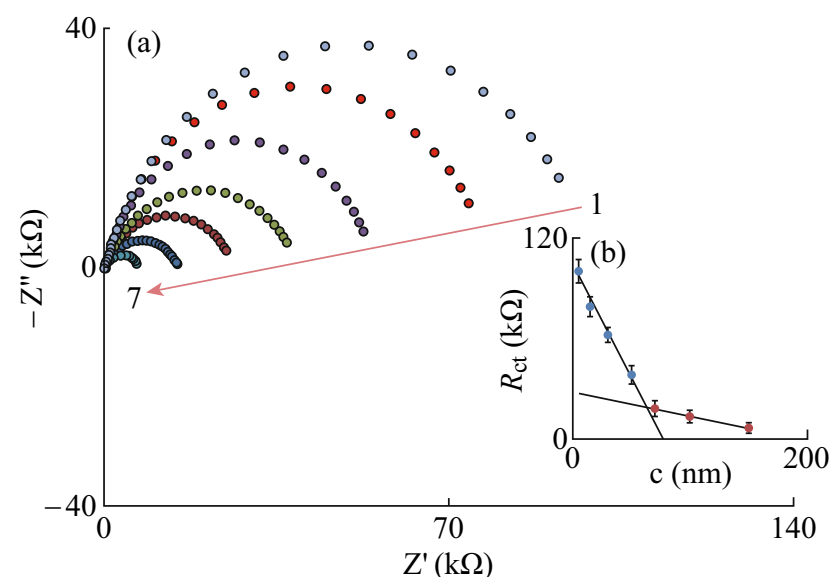

Fig. $11 a$ EIS response of $\mathrm{AgNPs} / \mathrm{CNT} / \mathrm{rGO} / \mathrm{MoO}_{2} / \mathrm{Sal}-\mathrm{His} / \mathrm{GC}$ in the presence of iodate with different concentrations (1-7) of 5, 15, 30, $50,70,100$, and $150 \mathrm{nM}$ in $0.1 \mathrm{M}$ PBS (pH 2.0) in the frequency range of $10 \mathrm{kHz}-0.1 \mathrm{~Hz} . b$ Corresponding calibration plot of $R_{\mathrm{ct}}$ versus iodate concentration

modified electrode are comparable or better than the results reported for $\mathrm{CySH}$ and iodate determinated at the surface of recently fabricated modified electrodes [33, 35-44].

\subsection{Study of Stability and Reproducibility}

In order to evaluate the long-term stability of the modified electrode and the reversibility of electrochemical behavior, the current and potential response of AgNPs/CNT/rGO/ $\mathrm{MoO}_{2} / \mathrm{Sal}-\mathrm{His}$ modified electrode were recorded before and after storing the electrode in ambient condition for 1 week. The response of modified electrode after 1 week indicates that the current and potential response of sensor remain almost unchanged. In addition, the operational stability of the modified electrode was monitored by recording 100 repetitive cycles at a scan rate of $50 \mathrm{mV} \mathrm{s}^{-1}$. No detectable change was observed in the peak height and potential separation after 100 repetitive cycles. The high stability of $\mathrm{AgNPs} / \mathrm{CNT} / \mathrm{rGO} / \mathrm{MoO}_{2} / \mathrm{Sal}$-His modified electrode may be related to the mechanical and chemical stability of $\mathrm{MoO}_{2} / \mathrm{Sal}$-His film at the surface of electrode, which can lead to its stabilization against desorption and avoid from leaching into the solution.

Furthermore, the reproducibility of the $\mathrm{MoO}_{2} / \mathrm{Sal}$-His/ AgNPs/CNT/rGO/GC modified electrode was tested by five repetitive measurements at various concentrations of CySH (5, 10, and $20 \mathrm{nM})$. The acceptable and reproducible signals with relative standard deviations (RSD) of 5.5, 6.1, and $4.1 \%$ are obtained.

\section{Conclusion}

In this study, a new bifunctional electrocatalyst was introduced and used as a modifier at the surface of GC electrode. The suitability of $\mathrm{AgNPs} / \mathrm{CNT} / \mathrm{rGO} / \mathrm{MoO}_{2} / \mathrm{Sal}-$ His as an ideal catalyst toward iodate reduction and $\mathrm{CySH}$ oxidation was demonstrated. The proposed bifunctional modified electrode exhibits significant advantages such as

Table 1 Electrochemical response of various modified electrodes for L-cysteine and iodate

\begin{tabular}{|c|c|c|c|c|c|}
\hline Electrode & Analyte & Applied potential & $\operatorname{LOD}(\mu \mathrm{M})$ & Linear range $(\mu \mathrm{M})$ & References \\
\hline $\mathrm{WO}_{3} / \mathrm{PANI} / \mathrm{GCE}$ & $\mathrm{IO}_{3}^{-}$ & -0.25 & 2.70 & $20.0-500$ & {$[35]$} \\
\hline AuNPs/P-3MTP & $\mathrm{IO}_{3}^{-}$ & -0.29 & 1.40 & $5.00-500$ & [36] \\
\hline $\mathrm{SiNH}_{3} \mathrm{PW}_{12}-\mathrm{CPE}$ & $\mathrm{IO}_{3}^{-}$ & -0.2 & 3.10 & $5.00-1000$ & {$[37]$} \\
\hline MWCNTs/[C $\left.\mathrm{C}_{8} \mathrm{Py}\right]\left[\mathrm{PF}_{6}\right]-\mathrm{PMo}_{12} / \mathrm{GCE}$ & $\mathrm{IO}_{3}^{-}$ & 0 & 15.0 & $20.0-2000$ & {$[38]$} \\
\hline AuNPs/PEI/CNTs-COOH/ORC & $\mathrm{IO}_{3}^{-}$ & +0.15 & 0.17 & $1.00-2000$ & {$[39]$} \\
\hline $\mathrm{Pt} / \mathrm{CNTs}$ & $\mathrm{CySH}$ & +0.48 & 0.30 & $0.50-1000$ & {$[40]$} \\
\hline Graphite/MWCNTs/AuNPs/CCE & $\mathrm{CySH}$ & +0.10 & 0.002 & $0.008-5.94$ & {$[41]$} \\
\hline $\mathrm{GNs} / \mathrm{MnO}_{2} / \mathrm{GCE}$ & $\mathrm{CySH}$ & & 0.108 & $1.44-1.73$ & {$[42]$} \\
\hline Ordered mesoporous carbon & $\mathrm{CySH}$ & +0.47 & 0.10 & $3.00-130$ & [43] \\
\hline $\mathrm{MnO}_{2}-\mathrm{C} / \mathrm{Chit} / \mathrm{GCE}$ & $\mathrm{CySH}$ & & 0.318 & $0.726-990$ & [44] \\
\hline \multirow[t]{2}{*}{ GC/AuNPs/PEI/GNs/ACA } & $\mathrm{IO}_{3}^{-}$ & +0.11 & 0.002 & $0.005-1.30$ & {$[33]$} \\
\hline & $\mathrm{CySH}$ & +0.05 & 0.30 & $1.00-15.0$ & \\
\hline \multirow[t]{2}{*}{$\mathrm{AgNPs} / \mathrm{CNT}-\mathrm{COOH} / \mathrm{rGO} / \mathrm{Mo}$} & $\mathrm{IO}_{3}^{-}$ & +0.45 & $1.2 \mathrm{nM}$ & $5-400 \mathrm{nM}$ & \\
\hline & $\mathrm{CySH}$ & +0.05 & 300 pM & $1.0-37.0 \mathrm{nM}$ & \\
\hline
\end{tabular}

$\mathrm{WO}_{3} / \mathrm{PANI}$, tungsten oxide/polyaniline; GCE, glassy carbon electrode; P-3MTP, poly (3-methylthiophene) composites; 3 -SiNH ${ }_{3}-\mathrm{PW}_{12}, \alpha$ $\mathrm{PW}_{12} \mathrm{O}_{40}^{-3}$ supported on the surface of aminopropyl(triethoxy)silane; CPE, carbon paste electrode; $\mathrm{MWCNTs} /\left[\mathrm{C}_{8} \mathrm{Py}\right]\left[\mathrm{PF}_{6}\right]-\mathrm{PMo}_{12}, \mathrm{multiwalled}$ carbon nanotubes/n-octylpyridinum hexafluorophosphate and 1:12 phosphomolybdic acid; PEI, polyethyleneimine; ORC, organoruthenium(II) complexes; CCE, carbon ceramic electrode; GNs, graphene nanosheets; Chit, chitosan 
low overpotential, high current density response, high sensitivity for iodate and $\mathrm{CySH}$ determination, and very good reproducibility and stability. It can be used as an impedimetric electrochemical sensor for monitoring of iodate and $\mathrm{CySH}$.

Acknowledgments The authors gratefully acknowledge the Khorramabad Branch, Islamic Azad University, for financial support.

Open Access This article is distributed under the terms of the Creative Commons Attribution 4.0 International License (http://crea tivecommons.org/licenses/by/4.0/), which permits unrestricted use, distribution, and reproduction in any medium, provided you give appropriate credit to the original author(s) and the source, provide a link to the Creative Commons license, and indicate if changes were made.

\section{References}

1. Y. Wang, Z. Shi, Y. Huang, Y. Ma, C. Wang, M. Chen, Y. Chen, Supercapacitor devices based on graphene materials. J. Phys. Chem. C 113(30), 13103-13107 (2009). doi:10.1021/jp902214f

2. J. Liang, Y. Xu, Y. Huang, L. Zhang, Y. Wang, Y. Ma, F. Li, T. Guo, Y. Chen, Infrared-triggered actuators from graphene-based nanocomposites. J. Phys. Chem. C 113(22), 9921-9927 (2009). doi:10.1021/jp901284d

3. G. Eda, M. Chhowalla, Graphene-based composite thin films for electronics. Nano Lett. 9(2), 814-818 (2009). doi:10.1021/ nl8035367

4. T. Ramanathan, A. Abdala, S. Stankovich, D. Dikin, M. HerreraAlonso et al., Functionalized graphene sheets for polymer nanocomposites. Nat. Nanotechnol. 3(1), 327-331 (2008). doi:10. 1038/nnano.2008.96

5. P. Si, H.L. Chen, P. Kannan, D. Kim, Selective and sensitive determination of dopamine by composites of polypyrrole and graphene modified electrodes. Analyst 136, 5134-5138 (2011). doi:10.1039/c1an15772h

6. T.A. Mir, M.H. Akhtar, N.G. Gurudatt, J.I. Kim, C.S. Choi, Y.B. Shim, An amperometric nanobiosensor for the selective detection of $\mathrm{K}$-induced dopamine released from living cells. Biosens. Bioelectron. 68, 421-428 (2015). doi:10.1016/j.bios.2015.01.024

7. A. Yu, P. Ramesh, M.E. Itkis, E. Bekyarova, R.C. Haddon, Graphite nanoplatelet-epoxy composite thermal interface materials. J. Phys. Chem. C 111(21), 7565-7569 (2007). doi:10.1021/ jp071761s

8. Y. Gan, L. Sun, F. Banhart, One- and two-dimensional diffusion of metal atoms in graphene. Small 4(5), 587-591 (2008). doi:10. 1002/smll.200700929

9. R. Muszynski, B. Seger, P.V. Kamat, Decorating graphene sheets with gold nanoparticles. J. Phys. Chem. C 112(14), 5263-5266 (2008). doi:10.1021/jp800977b

10. F. Lorestani, Z. Shahnavaz, P. Mn, Y. Alias, N.S. Manan, Onestep hydrothermal green synthesis of silver nanoparticle-carbon nanotube reduced-graphene oxide composite and its application as hydrogen peroxide senso. Sens. Actuat. B 208, 389-398 (2015). doi:10.1016/j.snb.2014.11.074

11. M. Hung, D.M. Stanbury, Catalytic and direct oxidation of cysteine by octacyanomolybdate (V). Inorg. Chem. 44(10), 443541-443550 (2005). doi:10.1021/ic050427c

12. G. Chwatko, E. Bald, Determination of cysteine in human plasma by high-performance liquid chromatography and ultraviolet detection after pre-column derivatization with 2-chloro-1- methylpyridinium iodide. Talanta 52(3), 509-515 (2000). doi:10. 1016/S0039-9140(00)00394-5

13. K. Arlt, S. Brandt, J. Kehr, Amino acid analysis in five pooled single plant cell samples using capillary electrophoresis coupled to laser-induced fluorescence detection. J. Chromatogr. A 926(2), 319-325 (2001). doi:10.1016/S0021-9673(01)01052-4

14. F. Tanaka, N. Mase, C.F. Barbas Iii, Determination of cysteine concentration by fluorescence increase: reaction of cysteine with a fluorogenic aldehyde. Chem. Commun. 15(15), 1762-1763 (2004). doi:10.1039/b405642f

15. S. Ge, M. Yan, J. Lu, M. Zhang, F. Yu, J. Yu, X. Song, S. Yu, Electrochemical biosensor based on graphene oxide-Au nanoclusters composites for L-cysteine analysis. Biosen. Bioelectron. 31(1), 49-54 (2012). doi:10.1016/j.bios.2011.09.038

16. H. Hosseini, H. Ahmar, A. Dehghani, A. Bagheri, A. Tadjarodi, A.R. Fakhari, A novel electrochemical sensor based on metalorganic framework for electro-catalytic oxidation of L-cysteine. Biosens. Bioelectron. 42(1), 426-429 (2013). doi:10.1016/j.bios. 2012.09.062

17. P. Das, M. Gupta, A. Jain, K.K. Verma, Single drop microextraction or solid phase microextraction-gas chromatographymass spectrometry for the determination of iodine in pharmaceuticals, iodized salt, milk powder and vegetables involving conversion into 4-iodo-N, N-dimethylaniline. J. Chromatogr. A 1023(1), 33-39 (2004). doi:10.1016/j.chroma.2003.09.056

18. A. Azadbakht, A.R. Abbasi, Fabrication of a highly sensitive hydrazine electrochemical sensor based on bimetallic Au-Pt hybrid nanocomposite onto modified electrode. Nano-Micro Lett. 2(1), 296-305 (2010). doi:10.1007/BF03353858

19. H. Ji, L. Zhu, D. Liang, Y. Liu, L. Cai, S. Zhang, S. Liu, Use of a 12-molybdovanadate (V) modified ionic liquid carbon paste electrode as a bifunctional electrochemical sensor. Electrochim. Acta 54, 7429-7434 (2009). doi:10.1016/j.electacta.2009.07.076

20. C.-D. Zhang, C.-Y. Sun, S.-X. Liu, H.-M. Ji, Z.-M. Su, An equatorial tri-iron substituted Wells-Dawson type tungstophosphate with magnetic and bifunctional electrocatalytic properties. Inorg. Chim. Acta 363(4), 718-722 (2010). doi:10.1016/j.ica. 2009.11.029

21. E. Zamanifar, F. Farzaneh, J. Simpson, M. Maghami, Synthesis, crystal structure and catalytic activity of a new Mo Schiff base complex with Mo histidine immobilized on Al-MCM-41 for oxidation of sulfides. Inorg. Chim. Acta 414(1), 63-70 (2014). doi:10.1016/j.ica.2014.01.028

22. G.J. Chen, J.W. Mc, Synthesis of molybdenum(IV) and molybdenum(V) complexes using oxo abstraction by phosphines. Mechanistic implication. Inorg. Chem. 15(11), 2612-2615 (1976). doi:10.1021/ic50165a008

23. Z. Derikvand, M.M. Olmstead, B.Q. Mercado, A. Shokrollahi, M. Shahryar, Solution and solid state studies of three new supramolecular compounds of zinc(II), nickel(II) and uranium(VI) with chelidamic acid and 9-aminoacridine. Inorg. Chim. Acta 406(1), 256-265 (2013). doi:10.1016/j.ica.2013.04. 041

24. O.A. Rajan, A. Chakravorty, Molybdenum complexes. 1. Acceptor behavior and related properties of $\mathrm{Mo}(\mathrm{VI}) \mathrm{O}_{2}$ (tridentate) systems. Inorg. Chem. 20(3), 660-664 (1981). doi:10.1021/ ic50217a005

25. Z. Asgharpour, F. Farzaneh, A. Abbasi, M. Ghias, Synthesis, crystal structure and DFT studies of a new dioxomolybdenum(VI) Schiff base complex as an olefin epoxidation catalyst. Polyhedron 101(1), 282-289 (2015). doi:10.1016/j.poly.2015.09. 030

26. N. Sumita Rao, M.N. Jaiswal, D.D. Mishra, R.C. Maurya, Synthesis and characterization of cis-dioxomolybdenum(VI) Schiff base complexes derived from 1-phenyl-3-methyl-4-benzoyl-5- 
pyrazolone. Polyhedron 12(16), 2045-2050 (1993). doi:10.1016/ S0277-5387(00)81479-5

27. R. Offeman, W. Hummers, Preparation of graphitic oxide. J. Am. Chem. Soc. 80(6), 1339 (1958). doi:10.1021/ja01539a017

28. L. Guadagnini, D. Tonelli, Carbon electrodes unmodified and decorated with silver nanoparticles for the determination of nitrite, nitrate and iodate. Sens. Actuat. B 188(1), 806-814 (2013). doi:10.1016/j.snb.2013.07.077

29. A.-K. Duhme-Klair, D.C.L. de Alwis, F.A. Schultz, Electrochemistry of molybdenum (VI)-catecholamide siderophore complexes in aqueous solution. Inorg. Chim. Acta 351(1), 150-158 (2003). doi:10.1016/S0020-1693(03)00210-X

30. A. Papadakis, A. Souliotis, E. Papaconstantinou, Functionalization of electrodes with polyoxometalates $\mathrm{P}_{2} \mathrm{Mo}_{18} \mathrm{O}_{62}{ }^{6-}$ and $\mathrm{P}_{2} \mathrm{~W}_{18} \mathrm{O}_{62}{ }^{6-}$. J. Electroanal. Chem. 435(1-2), 17-21 (1997). doi:10.1016/S0022-0728(97)00017-X

31. A.P. Brown, F.C. Anson, Cyclic and differential pulse voltammetric behavior of reactants confined to the electrode surface. Anal. Chem. 49(11), 1589-1595 (1977). doi:10.1021/ ac50019a033

32. J. Wang, Analytical Electrochemistry (VCH, New York, 1933), pp. 171-172. (1994 search PubMed)

33. A. Azadbakht, A.R. Abbasi, Z. Derikvand, Z. Karimi, The electrochemical behavior of Au/AuNPs/PNA/ZnSe-QD/ACA electrode towards CySH oxidation. Nano-Micro Lett. 7(2), 152-164 (2015). doi:10.1007/s40820-014-0028-y

34. T. Ralph, M. Hitchman, J. Millington, F. Walsh, The electrochemistry of 1-cystine and L-cysteine: part 1: thermodynamic and kinetic studies. J. Electroanal. Chem. 375(1-2), 1-15 (1994)

35. B.-X. Zou, X.-X. Liu, D. Diamond, K.-T. Lau, Electrochemical synthesis of WO 3/PANI composite for electrocatalytic reduction of iodate. Electrochim. Acta 55(12), 3915-3920 (2010). doi:10. 1016/j.electacta.2010.02.034

36. X. Huang, Y. Li, Y. Chen, L. Wang, Electrochemical determination of nitrite and iodate by use of gold nanoparticles/poly (3methylthiophene) composites coated glassy carbon electrode. Sens. Actuat. B 134(2), 780-786 (2008). doi:10.1016/j.snb.2008. 06.028

37. H. Hamidi, E. Shams, B. Yadollahi, F.K. Esfahani, Fabrication of bulk-modified carbon paste electrode containing $\alpha-\mathrm{PW}_{12} \mathrm{O}_{40}{ }^{3-}$ polyanion supported on modified silica gel: Preparation, electrochemistry and electrocatalysis. Talanta 74(4), 909-914 (2008). doi:10.1016/j.talanta.2007.07.026

38. B. Haghighi, H. Hamidi, L. Gorton, Formation of a robust and stable film comprising ionic liquid and polyoxometalate on glassy carbon electrode modified with multiwalled carbon nanotubes: Toward sensitive and fast detection of hydrogen peroxide and iodate. Electrochim. Acta 55(16), 4750-4757 (2010). doi:10. 1016/j.electacta.2010.03.041

39. A. Azadbakht, A.R. Abbasi, Z. Derikvand, S. Amraei, Immobilized organoruthenium (II) complexes onto polyethyleneiminewrapped carbon nanotubes/in situ formed gold nanoparticles as a novel electrochemical sensing platform. Mater. Sci. Eng. C 48(1), 270-278 (2015). doi:10.1016/j.msec.2014.12.034

40. S. Fei, J. Chen, S. Yao, G. Deng, D. He, Y. Kuang, Electrochemical behavior of L-cysteine and its detection at carbon nanotube electrode modified with platinum. Anal. Biochem. 339(1), 29-35 (2005). doi:10.1016/j.ab.2005.01.002

41. B.B. Prasad, R. Singh, A new micro-contact imprinted L-cysteine sensor based on sol-gel decorated graphite/multiwalled carbon nanotubes/gold nanoparticles composite modified sandpaper electrode. Sens. Actuat. B 212(9), 155-164 (2015). doi:10.1016/j. snb.2015.01.119

42. S.M. Majd, H. Teymourian, A. Salimi, Fabrication of an electrochemical L-Cysteine sensor based on graphene nanosheets decorated manganese oxide nanocomposite modified glassy carbon electrode. Electroanalysis 25(1), 2201-2210 (2013). doi:10. 1002/elan.201300245

43. J.C. Ndamanisha, J. Bai, B. Qi, L. Guo, Application of electrochemical properties of ordered mesoporous carbon to the determination of glutathione and cysteine. Anal. Biochem. 386(1), 79-84 (2009). doi:10.1016/j.ab.2008.11.041

44. C. Xiao, J. Chen, B. Liu, X. Chu, L. Wu, S. Yao, Sensitive and selective electrochemical sensing of 1-cysteine based on a caterpillar-like manganese dioxide-carbon nanocomposite. Phys. Chem. Chem. Phys. 13(4), 1568-1574 (2011). doi:10.1039/ C0CP00980F 